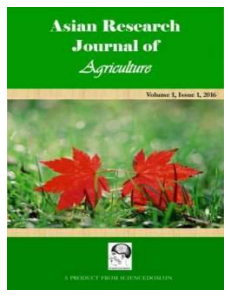

Asian Research Journal of Agriculture

3(4): 1-11, 2017; Article no.ARJA.31361

ISSN: 2456-561X

SCIENCEDOMAIN international

www.sciencedomain.org

\title{
Productivity, Energy Use Efficiency and Economics of Organic Scented Rice Cultivation in Sub-Humid Agroecosystem
}

\author{
A. Seal ${ }^{1}$, R. Bera ${ }^{1}$, R. Roy Chowdhury ${ }^{1}$, K. Mukhopadhyay ${ }^{1^{*}}$ and S. Mukherjee ${ }^{2}$ \\ ${ }^{1}$ Inhana Organic Research Foundation (IORF), 168 Jodhpur Park, Kolkata-700068, W.B., India. \\ ${ }^{2}$ Howrah Krishi Vigyan Kendra, ICAR, Howrah-711408, W.B., India.
}

Authors' contributions

This work was carried out in collaboration between all authors. All authors read and approved the final manuscript.

Article Information

DOI: $10.9734 /$ ARJA/2017/31361

Editor(s):

(1) Malgorzata Krzywonos, Department of Bioprocess Engineering, Wroclaw University of Economics, Wroclaw, Poland.

Reviewers:

(1) Rakesh Kumar, ICAR Research Complex for Eastern Region, Bihar, India.

(2) Hasan Vural, Uludag University, Turkey.

(3) Clifton Makate, UNEP-Tongji Institute of Environment for Sustainable Development, China Complete Peer review History: http://www.sciencedomain.org/review-history/18210

Original Research Article

Received $1^{\text {st }}$ January 2017

Accepted $1^{\text {st }}$ March 2017

Published $15^{\text {th }}$ March 2017

ABSTRACT

The increasing demand for organic cereals especially indigenous scented rice varieties in the recent years has peaked farmers' interest towards its organic production. However, the threat of crop loss under organic cultivation has been holding back large scale initiatives. Inhana Rational Farming (IRF) Technology has come up as a promising organic package of practice towards mitigating this drawback of organic production that too at an affordable economics. The present study was conducted to generate scientific information regarding organic scented rice cultivation (Oryza sativa var. 'Gobindobhog') utilizing this organic POP in terms of productivity, energy use efficiency and economics. The yield of scented rice cultivated using organic POP was found to be $18 \%$ higher than the conventionally grown ones. In terms of energy use efficiency as well, organic POP was calculated to be more efficient signifying the role of organic practice in sustainable agriculture. Net profitability of organic paddy increased up to $17 \%$ with a minimum premium price of $25 \%$. This increased higher income opportunity from same unit of land was an added benefit apart from improved soil quality in general; under organic management. 
Keywords: Scented rice; crop management; yield; energy use efficiency; organic cultivation.

\section{INTRODUCTION}

Introduction of high-yield varieties of rice during the Green Revolution had gradually pushed the traditional varieties to extinction as farmers were lured away by higher yields [1]. However, a report of Press Trust of India states that having lost the race to high-yielding varieties after the Green Revolution, a number of indigenous varieties of rice are now making a comeback due to their aroma, taste, low input cost and resilience to climate change [2]. The farmers' observations that fine aromatic rice have gradually lost their aroma, taste and yield due to lack of organic matter content in soil and changes in environment [3]; corroborates present day researches that indicate the potential of organic farming towards quality regeneration of scented rice [4]. Moreover the demand of aromatic rice is increasing day by day throughout the world for its taste and flavor and consumers are ready to pay a premium price for its organic version [5]. Hence, fine aromatic rice could be a potential choice for organic rice cultivation [6] and in this respect Oryza sativa var. 'Gobindobhog' is attracting farmers in West Bengal, due to higher productivity and remuneration [7]. But, information about the effects of organic management on scented rice particularly on this variety is very limited. Hence, the present investigation was conducted to generate scientific information on organic cultivation of scented gobindobhog rice utilizing Inhana Rational Farming (IRF) Technology, which has been showing promising results towards organic production of many other agricultural crops [8-11]. In this respect parameters viz. agronomy, yield, energy consumption and economics were considered for evaluation of the effectiveness of this method as against conventional cultivation practice.

\section{MATERIALS AND METHODS}

\subsection{Study Area}

The study was performed in the farm of Howrah Krishi Vigyan Kendra, Jagatballavpur of West Bengal, India. Situated in the hot moist subhumid agro-ecological zone of West Bengal, the region is built up from the alluvium deposited by Ganga and its tributaries and has annual rainfall between 1100 to $1500 \mathrm{~mm}$ of which, $75-80 \%$ is received during June to September. The mean annual maximum and minimum temperature are recorded to be $40.2^{\circ}$ and $10.8^{\circ} \mathrm{C}$ respectively with relative humidity ranging between 66 to $85 \%$. Gobindobhog is a premium scented rice variety cultivated traditionally in West Bengal. This rice variety was grown in the experimental plots during the aman (Rainy) season of 2015 when rainfall was in abundance.

\subsection{Experimental Protocol}

The crop was subjected to two types of cultivation package of practices (POP) viz., organic POP using Inhana Rational Farming (IRF) Technology and conventional POP using chemical fertilizers and pesticides.

The nursery bed was prepared according to the POP followed. In case of organic POP, Novcom compost prepared following Novcom Composting method [12] was applied in the nursery bed @ $150 \mathrm{~kg} /$ acre, whereas $2.8 \mathrm{~kg} \mathrm{~N}, 2.6 \mathrm{~kg} \mathrm{P}$ and 1.6 $\mathrm{kg} \mathrm{K}$ were applied in the form of chemical fertilizers in conventional nursery bed. Seeds under both POPs were subjected to seed treatment before sowing. Seeds for organic POP were treated with IRF recommended seed solution while seeds for conventional cultivation were soaked in Bavistin (Carbendazim) @ 90 $\mathrm{gm} / \mathrm{kg}$ seed and then sown in the nursery @ 18 $\mathrm{kg} / \mathrm{acre}$. The 35 days old seedlings were transplanted in the main field.

The main field was prepared by ploughinglevelling and nutrients were incorporated corresponding to the POP followed. In organic plots, Novcom compost was applied at the time of land preparation @ 6 ton / acre. Chemical fertilizers were applied in the conventional plots @ 24:12:12 kg/ acre of NPK but only $25 \%$ of total $\mathrm{N}, 100 \%$ of total $\mathrm{P}$ and $50 \%$ of total $\mathrm{K}$ were applied at the time of final land preparation. The rest was applied during $1^{\text {st }}$ top dressing ( 15 days after transplanting) and $2^{\text {nd }}$ top dressing (45 days after transplanting). Cartap hydrochloride $50 \%$ SP was sprayed in conventional rice cultivation when onset of stem borer (Scirpophaga incertulas) was observed. Although it was a rainfed crop, a dry spell during the panicle initiation stage necessitated irrigation that was given to both treatment plots. $1^{\text {st }}$ manual weeding was done two weeks after transplanting and continued as necessary throughout the growing season in the organic plots. But herbicide was 
used for weed control in the conventional POP following plots. The crop was harvested after 4 months from transplanting when the panicle turned slightly brown at the bottom and the plant was cut leaving a culm height of $25 \mathrm{~cm}$ above ground level.

\subsection{Agronomic Data Collection}

The necessary data required for assessing difference influenced by cultivation practice were recorded from ten randomly selected hills (each plant) from each POP following plot. Grain yield under both the treatments was determined from a $5 \mathrm{~m}^{2}$ sampling area from each plot, adjusted to $14 \%$ moisture, monitored by digital moisture meter (Steinlite, SL95, USA) and expressed as $\mathrm{t} / \mathrm{ha}$. Above ground biomass was the total dry matter of straw, rachis and filled and unfilled grains. Harvest Index was calculated to be $100 \times$ (grain weight / above ground total biomass) as suggested by Islam et al. [13].

The data were interpreted with statistical analysis viz. standard error and Duncan's multiple range test (MRT) using statistical package SPSS 11.5 .

\subsection{Inhana Rational Farming (IRF) Technology}

Inhana Rational Farming Technology is a comprehensive organic POP aimed towards farming rationally in harmony with nature. This technology was developed by an Indian scientist, Dr. P. Das Biswas, who had been associated with organic research activities for 15 years and this technology has been the fruit of his toiling; focusing towards an integrated approach to all the components of the ecosystem as a whole i.e. soil system, plant system and their interrelated and integrated relationships that go on to ensure sustainable agriculture. It works towards soil quality restoration, activation of plant physiology and reduction of pest/ disease pressure through alleviation of the root cause [8]. Objective of the technology is (i) Energization of the Soil System i.e., enabling the soil to function naturally and in the most effective way as an effective growth medium for plants and (ii) Energization of the Plant System i.e., supporting the plants to become nutrition efficient in terms of optimum extraction, utilization and assimilation of nutrients as well as enhancement of their biochemical and structural defense leading to enhanced host- defense mechanism. IRF recommends various in-house solutions for this purpose where technology specific plants, storing the energy of the five basic elements as well as five basic life forces are selected in accordance with parameters related to sunset, seasons and various factors. Following Element Energy Activation Principle (E.E.A.) energy are extracted from plants, and the potentized and energized solutions are applied individually or in combination as a complete package for working in an integrated manner giving comprehensive results [9].

IRF technology follows a protocol that manages crop production right from seed treatment till harvesting, for getting the best outcome. As mentioned earlier, seeds of organic POP were treated with seed solution- I, followed by IB $(\mathrm{Ag})-\mathrm{I}$ and IB $(\mathrm{Ag})$ - II when the seedlings were at 2 to 3 leaves stage in the nursery, at interval of 10 days. Just before transplanting in the main field, the seedlings were immersed in root deep water intermixed with Inhana Seed Solution- II and kept for one hour to erase out the possibility of any seed borne disease in future. 7 days post transplantation, IRF Plant Management Practice was initiated with a total of 8 rounds of different solutions sprayed at 7 to 10 days interval as per the detailed schedule mentioned in Table 1 . The purpose of action for these solutions is given in the Table 2.

The compost that was prepared with green matter following Novcom Composting method was analyzed in the laboratory for its quality as per the methodology mentioned by Black [14], Trautmann and Krasny [15] and Jackson [16].

Total energy input and output were calculated by substituting with energy equivalent of each operation in both the treatments. Details are provided in Table 3. Non- renewable energy consumed included diesel, chemical fertilizers, herbicides; pesticides, fungicides and machinery, and renewable energy consisted of human labor, compost, seed and water for irrigation [17]; which were calculated for each treatment. Energy use efficiency was calculated as described by Banaeian et al. [18]:

$$
\begin{aligned}
& \text { Energy use } \\
& \text { Efficiency }=
\end{aligned}
$$


Table 1. Spraying schedule for different Inhana solutions throughout the organic package of practice

\begin{tabular}{|c|c|c|c|}
\hline & Solution name & Dosage & Time of spraying \\
\hline \multicolumn{4}{|c|}{ Organic seed bed management } \\
\hline 1. & Seed solution- I & $0.1 \mathrm{ltr} / 10 \mathrm{ltr}$ of water & $\begin{array}{l}\text { Dipping of seeds for } 30 \text { minutes } \\
\text { and then sowing. }\end{array}$ \\
\hline 2. & IB $(\mathrm{Ag})-\mathrm{I}$ & $0.2 \mathrm{ltr} / \mathrm{ltr}$ of water & 3 days after germination \\
\hline 3. & IB $(\mathrm{Ag})-\mathrm{II}$ & $0.2 \mathrm{ltr} / \mathrm{ltr}$ of water & $\begin{array}{l}10 \text { days after } 1^{\text {st }} \text { spray i.e., that } \\
\text { of } \mathrm{IB}(\mathrm{Ag})-\mathrm{I} \text {. }\end{array}$ \\
\hline 4. & Seed solution- II & $0.2 \mathrm{ltr} / 5 \mathrm{Itr}$ of water & $\begin{array}{l}\text { Dipping of uprooted seedlings } \\
\text { just prior to transplantation. }\end{array}$ \\
\hline \multicolumn{4}{|c|}{ Organic rice management (Post transplantation) } \\
\hline 1. & $\mathrm{IB}(\mathrm{Ag})-1$ & $0.30 \mathrm{ltr} / \mathrm{acre}$ & 7 days after transplantation \\
\hline 2. & $\mathrm{IB}(\mathrm{Ag})-2+\mathrm{IB}(\mathrm{Ag})-7$ & $(0.30 \mathrm{ltr}+0.30 \mathrm{ltr}) / \mathrm{acre}$ & 17 days after transplantation \\
\hline 3. & $\mathrm{IB}(\mathrm{Ag})-4+\mathrm{IB}(\mathrm{Ag})-7$ & $(0.30 \mathrm{Itr}+0.30 \mathrm{ltr}) / \mathrm{acre}$ & 27 days after transplantation \\
\hline 4. & $\mathrm{IB}(\mathrm{Ag})-5$ & $0.30 \mathrm{Itr} / \mathrm{acre}$ & 37 days after transplantation \\
\hline 5. & $\mathrm{IB}(\mathrm{Ag})-2+\mathrm{IB}(\mathrm{Ag})-7$ & $(0.30 \mathrm{ltr}+0.30 \mathrm{ltr}) / \mathrm{acre}$ & 44 days after transplantation \\
\hline 6. & IB $(\mathrm{Ag})-3$ & $0.30 \mathrm{Itr} / \mathrm{acre}$ & 54 days after transplantation \\
\hline & $\mathrm{IB}(\mathrm{Ag})-5+\mathrm{IB}(\mathrm{Ag})-6$ & $(0.30 \mathrm{ltr}+0.30 \mathrm{ltr}) / \mathrm{acre}$ & 64 days after transplantation \\
\hline & $\mathrm{IB}(\mathrm{Ag})-3$ & $0.30 \mathrm{Itr} / \mathrm{acre}$ & 75 days after transplantation \\
\hline
\end{tabular}

Table 2. Purpose of action of the different Inhana solutions

\begin{tabular}{|c|c|c|c|}
\hline $\begin{array}{l}\text { SI. } \\
\text { no }\end{array}$ & $\begin{array}{l}\text { Solution } \\
\text { name }\end{array}$ & Extracts of plants & $\begin{array}{l}\text { Action of the solutions towards various } \\
\text { physiological functioning of the plants }\end{array}$ \\
\hline 1. & $\begin{array}{l}\text { Seed } \\
\text { solution -I }\end{array}$ & $\begin{array}{l}\text { Cynodon dactylon (L.) } \\
\text { Pers. and Calotropis } \\
\text { gigantea (L.) W.T.Aiton }\end{array}$ & $\begin{array}{l}\text { Increases the respiration rate of embryo - both aerobic } \\
\text { and anaerobic. }\end{array}$ \\
\hline 2. & IB $(\mathrm{Ag})-\mathrm{I}$ & Ficus hispida Linn. & Initiation of metabolic resources during germination. \\
\hline 3. & IB $(\mathrm{Ag})-\mathrm{II}$ & Erythrina variegata Linn. & $\begin{array}{l}\text { Faster independence of seedling from the seed } \\
\text { reserve. }\end{array}$ \\
\hline 4. & $\begin{array}{l}\text { Seed } \\
\text { solution II }\end{array}$ & $\begin{array}{l}\text { Hyoscyamus niger } \mathrm{L} \text {. and } \\
\text { Solanum verbascifolium } \mathrm{L} \text {. }\end{array}$ & $\begin{array}{l}\text { Photosynthesis enhancement and increased uptake of } \\
\text { organic and inorganic solutes through roots. }\end{array}$ \\
\hline 5. & IB $(\mathrm{Ag})-1$ & $\begin{array}{l}\text { Hyoscyamus niger } \mathrm{L} . \text {, } \\
\text { Ficus benghalensis } \mathrm{L} \text {. and } \\
\text { Dendrocalamus strictus } \\
\text { Nees. }\end{array}$ & $\begin{array}{l}\text { Organic growth promoter, activator and regulator: } \\
\text { Energizes and stimulates the plants system for best } \\
\text { use of inputs both applied and stored in the soil and } \\
\text { regulates every stage of the Grand Growth Period. }\end{array}$ \\
\hline 6. & IB (Ag)- 2 & $\begin{array}{l}\text { Ocimum sanctum L., } \\
\text { Calotropis procera R. \& } \\
\text { Cynodon dactylon (L.) } \\
\text { Pers. }\end{array}$ & $\begin{array}{l}\text { Silica induced immunity against Fungal Pathogens: } \\
\text { Activates plant's host defense mechanism through } \\
\text { Silica Management. It also stimulates plants Immune } \\
\text { System by activating the biosynthesis of phenolic } \\
\text { compounds and works as stress regulator. }\end{array}$ \\
\hline 7. & IB $(\mathrm{Ag})-3$ & $\begin{array}{l}\text { Adhatoda vasica Nees, } \\
\text { Zingiber officinale Roscoe } \\
\text { \& Embelia ribes Burm. }\end{array}$ & $\begin{array}{l}\text { Organic solution for potash absorption and utilization: } \\
\text { Increases the efficiency of potash uptake through } \\
\text { energized root capacity. It activates suction pressure } \\
\text { by influencing diffusion pressure deficit. }\end{array}$ \\
\hline 8. & $\mathrm{IB}(\mathrm{Ag})-4$ & $\begin{array}{l}\text { Calotropis procera R., } \\
\text { Dendrocalamus strictus } \\
\text { Nees and Bombax } \\
\text { malabaricum D. C. }\end{array}$ & $\begin{array}{l}\text { Ensures biological absorption and utilization of } \\
\text { atmospheric- } \mathrm{N} \text { by plant. It also balances the quantity of } \\
\text { nitrogen in the plant system at the right time and } \\
\text { thereby prevents deleterious effect on the quality of the } \\
\text { produce. It also ensures gradual reduction in chemical } \\
\text { nitrogen application. }\end{array}$ \\
\hline 9. & $\mathrm{IB}(\mathrm{Ag})-5$ & $\begin{array}{l}\text { Cynodon dactylon (L.) } \\
\text { Pers. \& Calotropis } \\
\text { gigantea (L.) W.T.Aiton }\end{array}$ & $\begin{array}{l}\text { Energizes the various biochemical process of plant } \\
\text { resulting in harmonious grand growth period. } \\
\text { Regulates and stimulates the cellular oxidation process } \\
\text { and energizes the phloemic function resulting in } \\
\text { encouraged translocation of organic solutes. } \\
\text { Stimulates the hydrolysis of starch to -D Glucose units } \\
\text { by enhancing the enzymatic activity. }\end{array}$ \\
\hline
\end{tabular}




\begin{tabular}{|c|c|c|c|}
\hline $\begin{array}{l}\text { SI. } \\
\text { no }\end{array}$ & $\begin{array}{l}\text { Solution } \\
\text { name }\end{array}$ & Extracts of plants & $\begin{array}{l}\text { Action of the solutions towards various } \\
\text { physiological functioning of the plants }\end{array}$ \\
\hline 10. & IB (Ag)-6 & $\begin{array}{l}\text { Hyoscyamus niger L. \& } \\
\text { Solanum verbascifolium L. }\end{array}$ & $\begin{array}{l}\text { Energizes and activates respiration and } \\
\text { photosynthesis activity and plays complementary role } \\
\text { of IB }(\mathrm{Ag})-5 \text {. It energizes respiration by activating the } \\
\text { protoplasmic factors and the concentration of } \\
\text { respiratory substrate. It also stimulates the rate of } \\
\text { photosynthesis by quick translocation of } \\
\text { carbohydrates. }\end{array}$ \\
\hline 11. & IB (Ag)- 7 & Ocimum sanctum L. & $\begin{array}{l}\text { Stimulates root function, activates root growth and } \\
\text { penetration and energizes soil in the root zone thus } \\
\text { improving soil-plant relationship. It also helps to } \\
\text { develop CEC of the soil, energizes the production of } \\
\text { microflora and bioflora around the root zone, improves } \\
\text { the degree of base saturation to the desired level, } \\
\text { enhances the root cation exchange capacity and } \\
\text { stimulates root growth and penetration by activating } \\
\text { contact exchange capacity of the root. }\end{array}$ \\
\hline
\end{tabular}

Table 3. Detailed calculation of the energy input and output under different treatments

\begin{tabular}{|c|c|c|c|c|c|c|}
\hline \multirow[t]{2}{*}{$\begin{array}{l}\text { Agriculture } \\
\text { operations }\end{array}$} & \multirow[t]{2}{*}{$\begin{array}{l}\text { Components } \\
\text { / inputs }\end{array}$} & \multirow{2}{*}{$\begin{array}{l}\text { Energy } \\
\text { equivalent } \\
\text { (MJ/unit) } \\
\text { [Reference] }\end{array}$} & \multicolumn{2}{|c|}{ Quantity of Agro-inputs } & \multicolumn{2}{|c|}{$\begin{array}{c}\text { Total energy equivalent } \\
\left(\mathrm{MJ}^{\text {acre }}{ }^{-1}\right)\end{array}$} \\
\hline & & & $\begin{array}{l}\text { Organic } \\
\text { POP }\end{array}$ & $\begin{array}{l}\text { Conventional } \\
\text { POP }\end{array}$ & $\begin{array}{l}\text { Organic } \\
\text { POP }\end{array}$ & $\begin{array}{l}\text { Conventio } \\
\text { nal POP }\end{array}$ \\
\hline \multicolumn{7}{|l|}{ Nursery } \\
\hline Seed \& Seed & Paddy Seed & $14.7[19]$ & $45 \mathrm{~kg}$ & $45 \mathrm{~kg}$ & 661.5 & 661.5 \\
\hline Treatment & Chemicals & 216 [20] & - & $0.09 \mathrm{~kg}$ & $-{ }^{*}$ & 19.44 \\
\hline Seed Bed & Machinery & $62.7[21]$ & $2.3 \mathrm{hrs}$ & $2.3 \mathrm{hrs}$ & 144.21 & 144.21 \\
\hline Preparation & Diesel & $56.31[22]$ & 11.6 Itrs & 11.6 Itrs & 653.2 & 653.2 \\
\hline Nutrient & Nitrogen (N) & $66.14[17]$ & - & $6.9 \mathrm{~kg}$ & - & 579.47 \\
\hline \multirow[t]{3}{*}{ Management } & $\begin{array}{l}\text { Phosphate } \\
\left(\mathrm{P}_{2} \mathrm{O}_{5}\right)\end{array}$ & $12.44[17]$ & - & $6.4 \mathrm{~kg}$ & - & - \\
\hline & Potassium & $11.15[17]$ & - & $3.9 \mathrm{~kg}$ & - & - \\
\hline & Compost & $0.30[23]$ & $375 \mathrm{~kg}$ & - & 112.5 & - \\
\hline \multicolumn{7}{|l|}{ Main field } \\
\hline Field & Machinery & $62.7[21]$ & $11.5 \mathrm{hrs}$ & $11.5 \mathrm{hrs}$ & 721.05 & 721.05 \\
\hline Preparation & Diesel & $56.31[22]$ & 58 Itrs & 58 Itrs & 3265.98 & 3265.98 \\
\hline Nutrient & Nitrogen (N) & $66.14[17]$ & - & $60 \mathrm{~kg}$ & - & 4676.1 \\
\hline \multirow[t]{3}{*}{ Management } & $\begin{array}{l}\text { Phosphate } \\
\left(\mathrm{P}_{2} \mathrm{O}_{5}\right)\end{array}$ & 12.44 [17] & - & $30 \mathrm{~kg}$ & - & - \\
\hline & $\begin{array}{l}\text { Potassium } \\
\left(\mathrm{K}_{2} \mathrm{O}\right)\end{array}$ & 11.15 [17] & - & $30 \mathrm{~kg}$ & - & - \\
\hline & Compost & 0.30 [23] & $15000 \mathrm{~kg}$ & - & 4500 & - \\
\hline $\begin{array}{l}\text { Plant } \\
\text { Protection }\end{array}$ & Pesticide & 229 [24] & - & $14.3 \mathrm{~kg}$ & - & 3274.7 \\
\hline $\begin{array}{l}\text { Inhana Plant } \\
\text { Management }\end{array}$ & $\begin{array}{l}\text { Inhana } \\
\text { Solutions }\end{array}$ & 0.08 [25] & $10.35 \mathrm{ltr}$ & - & 0.83 & - \\
\hline Irrigation & $\begin{array}{l}\text { Water } \\
\text { Pump }\end{array}$ & $\begin{array}{l}1.02[26] \\
62.7[21]\end{array}$ & $\begin{array}{l}4500 \mathrm{~m}^{3} \\
18 \mathrm{hrs}\end{array}$ & $\begin{array}{l}4500 \mathrm{~m}^{3} \\
18 \mathrm{hrs}\end{array}$ & $\begin{array}{l}4590 \\
1128.6\end{array}$ & $\begin{array}{l}4590 \\
1128.6\end{array}$ \\
\hline Weeding & Herbicide & 238 [20] & - & $1.5 \mathrm{~kg}$ & - & 357 \\
\hline Human labour & & 1.96 [20] & 292 & 201 & 4578.56 & 3151.68 \\
\hline $\begin{array}{l}\text { Total energy } \\
\text { Input }\end{array}$ & & & & & 20356 & 23223 \\
\hline
\end{tabular}

Note : * Organic seed treatment is included in Inhana Plant Management

The economics viz., cost, gross income and net return of the respective treatments were also worked following the standard techniques [27]. 


\section{RESULTS AND DISCUSSION}

\subsection{Compost Quality}

The compost sample prepared on farm was examined for its quality (Table 3 ). With a $\mathrm{pH}$ of 7.01 the compost qualifies to be good and matured [28]. Soluble salt concentration of compost is vital to know about its nutrient status; as too high or too low concentration can be detrimental to the growing plants. Electrical conductivity (EC) of the compost is well within the critical value of $4 \mathrm{dSm}^{-1}$ beyond which, most plants cannot tolerate the soluble salt content [29]. The ratio of available Carbon (C) to Nitrogen $(\mathrm{N})$ is a critical parameter for biodegradation and in most finished compost products, it is between 12 and 20 [30]. Hence, $\mathrm{C} / \mathrm{N}$ ratio of 17.5 indicates the compost to be matured and it is also within ideal suggested range of 12-18 [31]. Total microbial count in the order of $10^{16}$ signifies high microflora population indicating the compost to be of rich quality.

\subsection{Agronomic Traits}

Agronomic parameters were recorded at 90 days post transplantation stage for understanding the physiological growth of the crop. Kanbar et al, [32] revealed in their study that root to shoot length and root dry weight had the largest effect on plant height, shoot dry weight and grain yield; under well-watered condition. Length of both root and shoot as well as dry weight of both root and shoot was found to be higher in rice cultivated using organic POP (Figs. 1 and 2). This indicates that the overall nutrition and other physiological functioning of the plants under organic POP were better than the conventional counterpart that will ultimately lead to better yield of organic rice.

\subsection{Yield Attributing Agronomic Traits}

The parameters that directly account for yield are the manifestation of plant's physiological functioning along with its interaction with soil components. Fig. 3 reveals that albeit the no. of tillers/ hill was higher under conventional POP, but the effective tillers i.e., the ones bearing productive panicles was more in the organically grown rice plants. The panicle-bearing tiller rate influences the grain yield of rice [33] and formation of lowly productive tillers is considered an investment loss to the plant [34]. Formation of higher number of effective tillers in organic POP might be due to better management using IRF technology since tillering is also influenced by growing conditions and crop management practices [35].

Total number of grains/ panicle as well as filled grain/ panicle was recorded to be highest under organic POP and consequently the number of unfilled grains/panicle were around $20 \%$ lesser in organic rice than the conventional ones (Fig. 4). Nutrients during flowering stage are critical for proper filling up of grains [36]; but despite adequate nutrient resource in both the POP, the conventional rice had higher number of unfilled grains/ panicle. This could be due to uneven dry matter allocation per spikelet from heading to maturity [37] and low activities of key enzymes in carbon metabolism during grain- filling stage [38]. Better filling of grains in organic rice using IRF technology might be the impact of the botanical extracts which provide the necessary energy for efficient plant metabolism.

\subsection{Yield}

Better agronomic as well as other yield attributing traits might have led to higher rice yield under Organic POP. Also, it has been often suggested that yield increase of rice depends more on translocation of biomass accumulated to kernels before heading, than on biomass accumulation from heading to maturity [39-40]. Thus higher yield of rice under organic management could perhaps be attributed to better translocation of biomass to the respective sites i.e., enhanced plant physiological functions; as brought about by application of different plant management solutions under IRF technology [9].

Table 4. Parameters determining the quality of the prepared compost

\begin{tabular}{llll}
\hline SI no & Parameters & \multicolumn{2}{c}{ Novcom compost } \\
\cline { 3 - 4 } & & Range Value & Mean \pm Std. E. \\
\hline 1. & $\mathrm{pH}_{\text {water }}(1: 5)$ & $6.14-7.47$ & $7.01 \pm 0.12$ \\
2. & $\mathrm{EC}\left(\mathrm{dSm}^{-1}\right)$ & $2.29-3.12$ & $(2.67)[ \pm 0.11]$ \\
3. & Organic carbon $(\%)$ & $28.12-34.14$ & $31.14 \pm 1.28$ \\
4. & Total NPK $(\%)$ & $3.14-3.89$ & $3.34 \pm 0.13$ \\
5. & C/N ratio & $14.9: 1-17.3: 1$ & $16.2: 1 \pm 0.11$ \\
6. & Total microbial count(per gm moist compost) & $(33-57) \times 10^{16}$ & $43 \times 10^{16} \pm .9 \times 10^{16}$ \\
10. & Germination index (phytotoxicity bioassay) & $0.85-1.14$ & $1.04 \pm 0.02$ \\
\hline
\end{tabular}




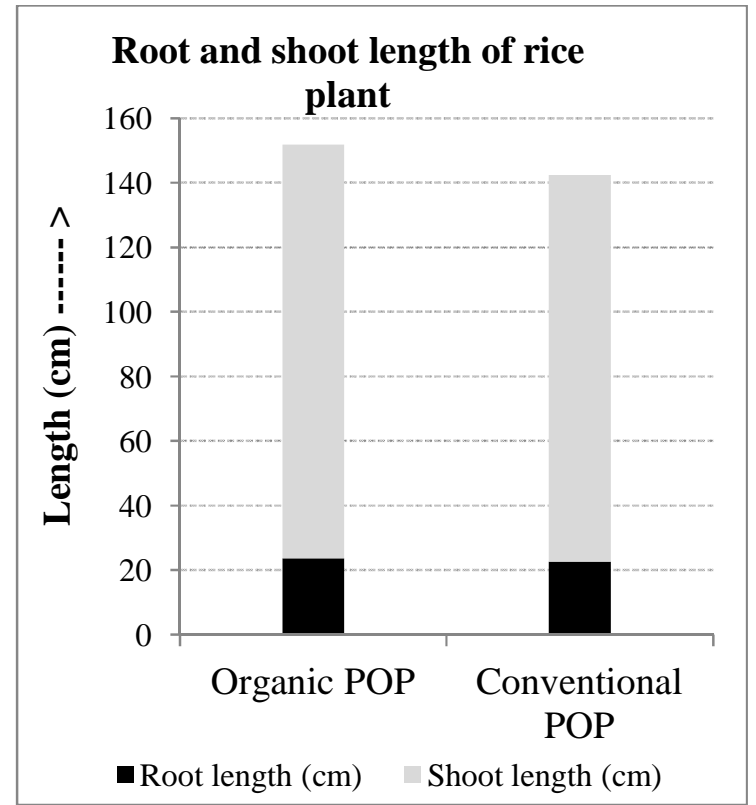

Fig. 1. Root and shoot length comparison between two treatments at 90 days post transplantation.

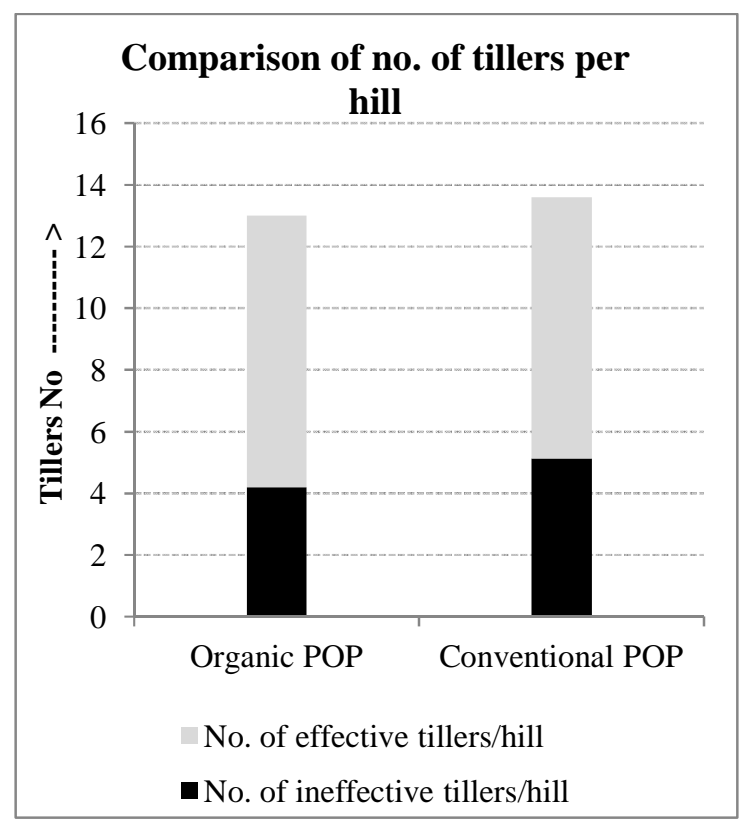

Fig. 3. Comparison of the no. of tillers, effective tillers produced under each management practices

\subsection{Harvest Index}

The harvest index $(\mathrm{HI})$ is the grain yield over total above-ground biomass [41] and variations in

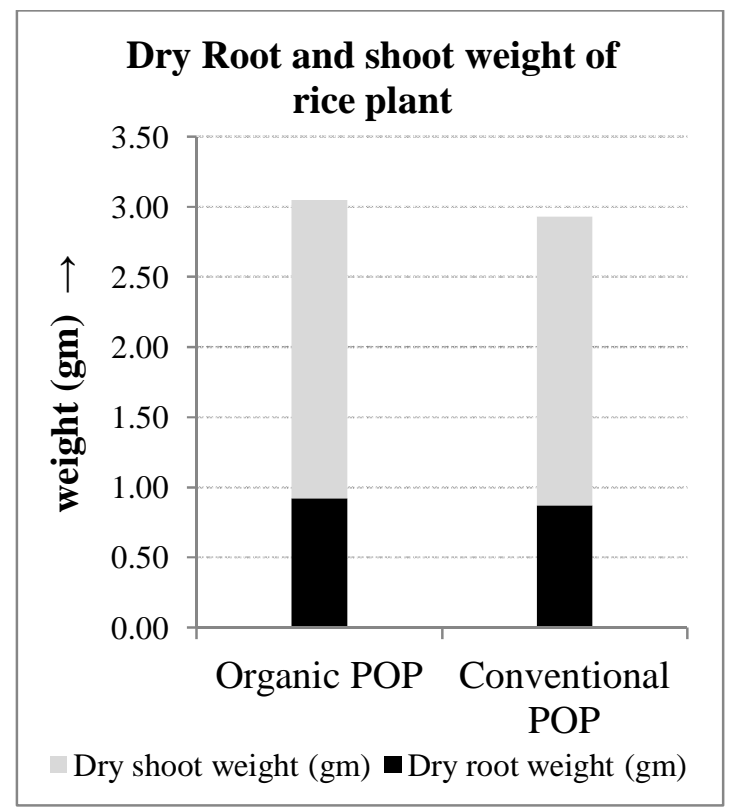

Fig. 2. Dry root and dry shoot weight of rice plant comparison at 90 days post transplantation stage

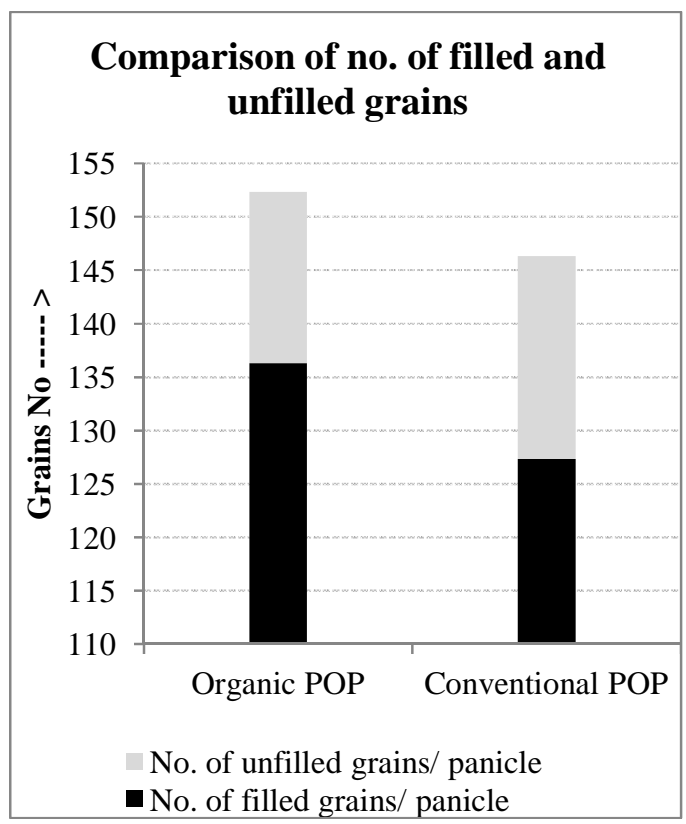

Fig. 4. Comparison of no. of filled and unfilled grains/panicle produced in rice plants under different management practices

harvest index within a crop are mainly attributed to differences in crop management [42]. Similar result has also been observed in the present study where the $\mathrm{HI}$ varied between rice cultivated 
Table 5. Yield, economics and energetics of rice cultivation under different treatments

\begin{tabular}{|c|c|c|}
\hline Treatment & $\begin{array}{l}\text { Organic package of } \\
\text { practice }\end{array}$ & $\begin{array}{l}\text { Conventional package of } \\
\text { practice }\end{array}$ \\
\hline Yield (ton acre ${ }^{-1}$ ) & $1.28^{* x} \pm 0.08$ & $1.09 \pm 0.09$ \\
\hline Harvest Index (\%) & $55.99 \pm 1.24$ & $55.41 \pm 1.09$ \\
\hline Net income from cultivation (Rs acre ${ }^{-1}$ ) & $44639^{\overline{k+}} \pm 123.2^{\#}$ & $32457 \pm 129.4$ \\
\hline Profit / $\mathrm{kg}$ produce $\left(\mathrm{Rs} \mathrm{kg}^{-1}\right)$ & $34.93^{*} \pm 1.03$ & $29.76 \pm 1.02$ \\
\hline Energy Use Efficiency & $2.55^{* *} \pm 0.01$ & $2.07 \pm 0.04$ \\
\hline Renewable Energy used (MJ acre ${ }^{-1}$ ) & $4814^{* *} \pm 37.2$ & $2809 \pm 35.5$ \\
\hline Non Renewable Energy used (MJ acre ${ }^{-1}$ ) & $1971 \pm 30.1$ & $4931^{* \star} \pm 39.8$ \\
\hline
\end{tabular}

utilizing organic POP and its conventional counterpart (Table 4); organic rice having slightly higher value. This might be due to increase in growth rate during grain growth and/or enhanced remobilization of assimilates from vegetative tissues to grains, during the grain-filling period [43].

\subsection{Economics}

Organic crops are considered as value added products and so fetch premium price in the market. But the multi-layered system of middlemen involved in the distribution of produce from farm to fork [44] hinder the direct access of the farmers to the premium price, that can be procured under organic rice cultivation. As per different reports obtained regarding market price of organic rice and related profitability, organic farmers obtained about 25 to $30 \%$ higher price, which compensated the yield loss suffered under organic [45,46]. However, most of the organic farmers feel that marketability is the major problem. In the present experimentation, crop yield was higher than conventional, however cost of cultivation under organic is higher than that of conventional especially due to higher mandays requirement for different operation and higher cost of nutrient management under organic. But the most significant fact is that with mere $1.5 \%$ higher premium, same net income as under conventional could be achieved. Hence, considering $25 \%$ premium price, farmers can get $17 \%$ higher profit per $\mathrm{kg}$ organic rice. This can open the scope for higher income generation from same unit of land, apart from soil quality development, which although not considered in the profit loss assessment might be the most important investment in the whole exercise.

\subsection{Energetics}

Energy use efficiency of a management system defines its role in developing sustainable agriculture. Rice cultivation following organic POP was found to be more energy efficient than conventional cultivation since usage of fossil energy was minimal and yield was higher under organic practice. Application of agrochemicals in conventional rice cultivation increases energy consumption and thereby reduces energy efficiency. Many workers have found organic cultivation to be more energy efficient when working with varied crops [21,47-49]. While differentiating renewable and non-renewable energy usage in rice cultivation, it was found that cultivation following organic POP consumed $71 \%$ more renewable energy and very less nonrenewable energy as compared to onventional practice. Usage of petrochemicals and fossil fuel energy for synthesis of chemical fertilizers and pesticides increased the non- renewable energy use in conventional POP. Environmental damage caused by GHG emissions and exhaustion of finite natural resources can be mitigated by promotion of renewable energy usage [50]. Hence, higher usage of renewable energy under organic POP (IRF technology) can be considered as a powerful step towards the goal of sustainable agriculture.

\section{CONCLUSION}

The present study revealed that organic cultivation of scented rice (variety 'Gobindobhog') can ensure sustainable agriculture both in terms of crop and economics; through minimal usage of finite natural resources. The opinion of organic cultivation being less remunerative has also been contradicted in the present study as higher yield could be obtained under this cultivation system. The results indicated that in the aftermath of prolonged agrochemical usage; activation of the physiological functioning of the plant system has significance towards revival of crop health leady to economic yield, which cannot be brought about through management of soil fertility alone. However, apart from the economic returns, the 
added benefit of soil fertility development has long term benefits which will go on increasing in the realms of organic cultivation broadening the performance margin between conventional and organic method of cultivation. Thus IRF technology can be considered as a trustable gismo towards effective organic rice cultivation with special mention of scented rice variety.

\section{COMPETING INTERESTS}

Authors have declared that no competing interests exist.

\section{REFERENCES}

1. The Hindu, Press Trust of India. Climate change makes Sunderbans farmers opt for traditional seeds. The Hindu, India; 2013.

2. The Times of India, Press Trust of India, 2015. Taste, cost and climate change prompt return of folk rice; 2015.

Available:http://timesofindia.indiatimes.com /india/Taste-cost-and-climate-change-

prompt-return-of-folk-

rice/articleshow $/ 47983914 . \mathrm{cms}$

[Cited 20 Sept, 2015]

3. Singh RK, Ozkan US. Indigenous scented rices: Farmers perception and commitment. Paper presented at International Conference on Creativity and Innovation at Grassroots, Hyderabad; 1997.

4. Bora D, Goswami J, Saud RK, Begum M. Effect of organic inputs on production and quality of scented rice (Oryza sativa) variety ketekijoha in Assam and its economic aspect. Agric. Sci. Digest. 2014; 34(2):115-118.

5. Louis MTB, Robert JH, Qingsheng J, Russell FR, Daniel LEW. A perfect marker for fragrance genotyping in rice. Molecular Breeding. 2005;16:279-283.

6. Hossain ST, Sugimoto $\mathrm{H}$, Ueno $\mathrm{H}$, Rafiul SM. Adoption of organic rice for sustainable development in Bangladesh. Journal Organic Systems. 2007;2(2):2737.

7. Pramanik A. Bengal's aromatic Gobindo Bhog rice attracts more farmers. Published in: The Hindu Business line; 2013.

8. Bera R, Seal A, Datta A, Sengupta K. Evaluation of Inhana rational farming technology as an organic package of practice for effective and economic vegetable cultivation in farmers' field. J. Nat. Prod. Plant Resour. 2014;4(3):82-91.
9. Barik AK, Chatterjee AK, Datta A, Bera R, Seal A. Evaluation of Inhana rational farming (IRF) technology as an effective organic package of practice- a case study from state horticultural research and development station, Krishnagar, Nadia, West Bengal. Central European Journal of Experimental Biology. 2014;3(3):1-15.

10. Barik AK, Chatterjee AK, Seal A, Datta A, Saha S, Bera R. Evaluation of Inhana rational farming (IRF) technology as a cost effective organic cultivation method in farmer's field. Research \& Reviews: Journal of Crop Science and Technology. 2015;5(1):1-16.

11. Seal A, Bera R, Datta A, Saha S, Dolui AK, Chatterjee AK, Sarkar RK, De GC, Barik AK, Sengupta K, Majumdar D. Appraisal of inhana rational farming (IRF) technology as a road map for ecologically and economically sustainable organic crop production- The future foundation for higher productivity. In National Symposium on In Quest of a Second Green Revolution. Held on Feb 26-28, Institute of Agricultural Sci., Univ. of Calcutta, India; 2013.

12. Seal A, Bera R, Chatterjee AK, Dolui AK. Evaluation of a new composting method in terms of its biodegradation pathway and assessment of compost quality, maturity and stability. Archives of Agronomy and Soil Science. 2012;58(9):995-1012.

13. Islam MS, Peng S, Visperas RM, Bhuiya MS, Hossain SMA, Julfiquar AW. Comparative study on yield and yield attributes of hybrid, inbred, and NPT rice genotypes in a Tropical Irrigated Ecosystem. Bangladesh J. Agril. Res. 2010;35(2):343-353.

14. Black CA. Methods of soil analysis: Part 1 and 2, American Society of Agronomy Inc. Madison, Wisconsin, USA; 1965.

15. Trautmann NM, Krasny ME. Composting in the classroom; 1997.

Available:http://www.cfe.cornell.edu/compo st/schools.html

(Accessed 27.04. 16)

16. Jackson ML. Soil chemical analysis. Prentice Hall of India Pvt. Ltd., New Delhi; 1973.

17. Mohammadi A, Tabatabaeefar A, Shahin S, Rafiee S, Keyhani A. Energy use and economical analysis of potato production in Iran, a case study: Ardabil province. Energy Conversation and Managegment. 2008;49:3566-70. 
18. Banaeian N, Omid M, Ahmadi H. Energy and economic analysis of greenhouse strawberry production in Tehran province of Iran. Energy Conversion and Management. 2011;52(2):1020-1025.

19. Singh S, Mittal JP. Energy in production agriculture. Mittal Pub., New Delhi; 1992.

20. Ozkan B, Fert C, Karadeniz CF. Energy and cost analysis for greenhouse and open-field grape production. Energy. 2007; 32:1500-1504.

21. Gündogmus E, Bayramoglu Z. Energy input use on organic farming: A comparative analysis on organic versus conventional farms in Turkey. Journal of Agronomy. 2006;5(1):16-22.

22. Yilmaz I, Akcaoz H, Ozkan B. An analysis of energy use and input costs for cotton production in Turkey. Renew Energy. 2005;30:145-155.

23. Heidari MD, Omid M, Mohammadi A. Measuring productive efficiency of horticultural greenhouses in Iran: A data envelopment analysis approach. Expert Systems with Applications. 2012;39:10401045.

24. Kitani O. Energy and Biomass Engineering. CIGR Handbook of Agricultural Engineering. ASAE Publication. St. Joseph, MI. 1999;5:330.

25. Pal K. Adoption of a crop management system towards integrated soil management and zero pesticide use in potato (Solanum Tuberosum L.) cultivation. M.Sc. thesis. Department of Agricultural Chemistry and Soil Science, University of Calcutta, Kolkata; 2016.

26. Canakci M, Akinci I. Energy use pattern analyses of greenhouse vegetable production. Energy. 2006;31:1243-1256.

27. Sita Devi K, Ponnarasi T. An Economic analysis of modern rice production technology and its adoption behaviour in Tamil Nadu. Agricultural Economics Research Review. (Conference Number). 2009;22:341-347.

28. Jime'nez IE, Garcia PV. Evaluation of city refuse compost maturity: A review. Biological Wastes. 1989;27:115-42.

29. Mamo M, Halbach T, Rosen C. Utilization of MSW compost for crop production. University of Minnesota; 2002.

Available:http://www.extension.umn.edu/di stribution/natu ral resources/DD 7083.htm/ (Accessed 23.11.16)

30. Rynk R, van de Kamp M, Willson GB, Singley ME, Richard TL, Kolega JJ, Gouin
FR, Laliberty Jr. L, Kay D, Murphy DW, Hoitink HAJ, Brinton WF. The composting process, characteristics of raw materials. In: On-Farm Composting Handbook, edited by R. Rynk, NRAES-54, Cornell University Press, Ithaca, NY. 1992;6-13:106-113.

31. Cal recycle. Organic materials management-compost-what is it?; 2006. Available:http://www.calrecycle.ca.gov/org anics/compostmulch/Compostls.htm (Accessed 3.3. 2013)

32. Kanbar A, Toorchi M, Shashidhar HE. Relationship between root and yield morphological characters in rainfed low land rice (Oryza sativa L.). Cereal Research Communications. 2009;37(2): 261-268.

33. Wang F, Cheng FM, Zhang GP. Difference in grain yield and quality among tillers in rice genotypes differing in tillering capacity. Rice Sci. 2007;14:135-140.

34. Badshah MA, Naimei' T, Zou Y, Ibrahim $\mathrm{M}$, Wang $\mathrm{K}$. yield and tillering response of super hybrid rice Liangyoupeijiu to tillage and establishment methods. The Crop Journal. 2014;2(1):79-86.

35. Wopereis MCS, Defoer T, Idinoba P, Diack S, Dugué MJ. Participatory learning and action research (PLAR) for integrated rice management (IRM) in inland valleys of Sub- Saharan Africa: Technical Manual. Africa Rice Center, Côte d'Ivoire; 2009.

36. Nas M, Fin, L. Fill those grains: Nutrients are critical during flowering stage. Article published in: Manila Bulletin Agriculture Magazine. 2012;1-3.

37. Adam B, Puteh M. Mondal MA, Ismail MR, Latif MA. Grain sterility in relation to dry mass production and distribution in rice (Oryza sativa L.). BioMed Research International. 2014;1-6.

Available:http://dx.doi.org/10.1155/2014/30 $\underline{2179}$

38. Yang J, Zhang J. Grain-filling problem in 'super' rice. J. Exp. Bot. 2010;61(1):1-5. DOI: 10.1093/jxb/erp348

39. Miah MNH, Oshida TY, Yamamoto Y, Nitta Y. Characteristics of dry matter production and partitioning of dry matter in high yielding semi-dwarf indica and japonicaindica hybrid rice varieties. Jpn J. Crop. Sci. 1996;65:672-685.

40. Laza RC, Peng S, Akita S, Saka H. Contribution of biomass partitioning and translocation of grain yield under suboptimum growing conditions in irrigated rice. Plant Prod. Sci. 2003;6:28-35. 
41. Yang J, Zhang J. Crop management techniques to enhance harvest index in rice. J. Exp. Bot; 2010.

DOI: $10.1093 / \mathrm{jxb} / \mathrm{erq} 112$

42. Peltonen-Sainio P, Muurinen S, Rajala A, Jauhiainen $L$. Variation in harvest index of modern spring barley, oat and wheat cultivars adapted to northern growing conditions. Journal of Agricultural Science. 2008;146:35-47.

43. Fletcher AL, Jamieson PD. Causes of variation in the rate of increase of wheat harvest index. Field Crops Research. 2009;113:268-273.

44. Khodaskar KP. Virtual fruits market. International Journal of Science and Research. 2012;3(12):1591-1593.

45. Guri RK, Kunnal LB, Chourad R. Comparative study of organic and inorganic paddy with reference to yield, market price and returns. Internationl Research Journal of Agricultural Economics and Statistics. 2014;5(1):9-15

46. Charyulu DK, Biswas, S. Economics and efficiency of organic farming vis-à-vis.
Conventional Farming in India. W.P. No. 2010-04-03. 2010;2-26.

Available:http://www.iimahd.ernet.in /assets/snippets/workingpaperpdf/201004-03Charyulu.pdf

47. Hoeppner J, Hentz M, McConkey B, Zentner R, Nagy C. Energy use and efficiency in two Canadian organic and conventional crop production systems. Renewable Agriculture and Food Systems. 2006;21(1):60-67.

48. Dalgaard T, Halberg N, Porter JR. A model for fossil energy use in Danish agriculture used to compare organic and conventional farming. Agriculture, Ecosystems and Environment. 2001;87:51-65.

49. Pimentel D, Hepperly P, Hanson J, Douds $D$, Seidel R. Environmental, energetic, and economic comparisons of organic and conventional farming systems. Bio Science. 2005;55(7):573-582.

50. Chel A, Kaushik G. Renewable energy for sustainable agriculture. Agron. Sustain. Dev. 2011;31:91-118.

(c) 2017 Seal et al.; This is an Open Access article distributed under the terms of the Creative Commons Attribution License (http://creativecommons.org/licenses/by/4.0), which permits unrestricted use, distribution, and reproduction in any medium, provided the original work is properly cited.

Peer-review history:

The peer review history for this paper can be accessed here: http://sciencedomain.org/review-history/18210 